\title{
SOCIOLOGY AND THE THEORY OF DOUBLE CONSCIOUSNESS
}

\section{W. E. B. Du Bois's Phenomenology of Racialized Subjectivity}

\author{
José Itzigsohn \\ Department of Sociology, Brown University \\ Karida Brown \\ Department of Sociology, Brown University
}

\begin{abstract}
In this paper we emphasize W. E. B. Du Bois's relevance as a sociological theorist, an aspect of his work that has not received the attention it deserves. We focus specifically on the significance of Du Bois's theory of Double Consciousness. This theory argues that in a racialized society there is no true communication or recognition between the racializing and the racialized. Furthermore, Du Bois's theory of Double Consciousness puts racialization at the center of the analysis of self-formation, linking the macro structure of the racialized world with the lived experiences of racialized subjects. We develop our argument in two stages: The first section locates the theory of Double Consciousness within the field of classical sociological theories of the self. We show how the theory addresses gaps in the theorizing of self-formation of James, Mead, and Cooley. The second section presents an analysis of how Du Bois deploys this theory in his phenomenological analysis of the African American experience. The conclusions point out how the theory of Double Consciousness is relevant to contemporary debates in sociological theory.
\end{abstract}

Keywords: Du Bois, Double Consciousness, Self, Sociological Theory, Misrecognition, Phenomenology

I could see that the scientific task of the twentieth century would be to explore and measure the scope of chance and unreason in buman action, which does not yield to argument but changes slowly and with difficulty after long study and careful development.

—W. E. B. Du Bois, Dusk of Dawn (1940, p. 7)

Du Bois Review, 12:2 (2015) 231-248.

(C) 2015 Hutchins Center for African and African American Research 1742-058X/15 \$15.00

doi:10.1017/S1742058X15000107 


\section{INTRODUCTION}

Sociology ignored the work of W. E. B. Du Bois for a long time. Of late, however, the discipline has begun to recognize his work, paying attention to his urban and community studies and reflecting on how incorporating his insights could have changed the practice of sociology (Anderson 1996, 2000; Bobo 2000; Green and Driver, 1995; Morris 2007; Morris and Ghaziani, 2005; Wortham 2009, 2011; Zuberi 2004).Yet Du Bois's work as a sociological theorist continues to go overlooked (England and Warner, 2013; Zukerman 2004). Du Bois is thought to be a scholar of race, and he is indeed that. But his work goes beyond treating race as a discrete concept and instead situates the process of racializing and racialization (i.e., the process of intersubjectively constructing racial categories and meanings that structure the experiences of groups and individuals) at the core of the formation and the organization of the modern world. His oeuvre, which has a thematic unity over the course of nearly seven decades, was developed in a large corpus of writings in the form of empirical studies, essays, journalistic pieces, speeches, and theoretical reflections. In it, Du Bois develops a micro-analysis of self- and group-identity formation under conditions of racialization as well as a macroanalysis of the racialized world. This body of work, we argue, makes Du Bois a theorist of racialized modernity and situates his work as central to classical sociological theory and to contemporary theoretical debates.

In this article we emphasize the significance of Du Bois's theory of Double Consciousness for sociological theory and analysis. Developed mainly in Souls of Black Folk (1903) and Dusk of Dawn (1940) (hereafter, Souls and Dusk, respectively), the theory of Double Consciousness is a phenomenological description of self-formation under conditions of racialization. The theory has long been part of debates among scholars of African American studies (Gilroy 1993; Gooding-Williams 2010; Gordon 2000; Rabaka 2010; Rampersad 1976; Reed 1997; Smith 2004; Zamir 2008). Its sociological importance, however, is barely acknowledged (Blau and Brown, 2001; Lemert 1994; Rawls 2000). Yet, as Charles Lemert argues:

Du Bois's double self concept deserved a prominent place in the lineage of self theorists which, from James and Baldwin through Cooley to Mead to the symbolic interactionists, has been one of Sociology's proudest traditions (1994, p. 389).

We go further to argue that the theory of Double Consciousness is central to the analysis of the self within the context of the modern racialized world. We develop our argument in two stages: The first section locates the theory of Double Consciousness within the field of sociological theories of the self developed by Du Bois's contemporaries. We argue that Du Bois was able to see the process of self-formation in a much sharper way than other self theorists who were blind to the presence and effects of the veil. The second section presents an analysis of how Du Bois deployed this theory in his phenomenological analysis of self-formation in a racialized world. Finally, the conclusions point to the relevance of the theory of Double Consciousness for contemporary social theory debates.

\section{DOUBLE CONSCIOUSNESS AND THE THEORIZATION OF THE SELF}

The main argument of sociological theories of the self is that the self is the result of social processes, constructed and reconstructed through ongoing social interaction. At the core of this argument are the acts of mutual recognition and communication between individuals in society, elements upon which the classical theorists-William 
James, George Herbert Mead, and Charles Horton Cooley-base their arguments. We argue that Du Bois's theory of Double Consciousness illuminates a point that remains unaddressed by these three theorists: the limits to communication and to mutual recognition under conditions of racialization. Du Bois argues that the color line creates different processes of self-formation among racializing and racialized groups (Lemert 1994; Rawls 2000).

The early theorization of the self starts with James's The Principles of Psychology (1890), in which he divides the self between the "I" (the self as knower) and the empirical self, or "me" (the self as known, the accumulated experiences that constitute the self). James further divides the "me" into four components: the material self (our material existence, our bodies, our families, our possessions), the spiritual self (our states of consciousness and feelings), the pure Ego, and, most importantly in this context, the social self. The social self emerges through interaction and mutual recognition between people and from the internalization of the images that the other carries of us. Lack of recognition has a devastating impact in the formation of the self. Of this condition James writes:

No more fiendish punishment could be devised, were such a thing physically possible, than that one should be turned loose in society and remain absolutely unnoticed by all the members thereof. If no one turned round when we entered, answered when we spoke or minded what we did, but if every person we met "cut us dead" and acted as if we were non-existing things, a kind of rage and impotent despair would ere long well up in us, from which the cruelest bodily tortures would be a relief; for those would make us feel that, however bad might be our plight, we had not sunk to such a depth as to be unworthy of attention at all (1890, p. 293).

Recognition is so crucial to one's own subjective understanding that we may develop as many social selves as there are individuals that recognize us (James 1890, p. 294). In this formulation, this splitting divides us into several selves. Further, these split selves tend to adopt group positions that may be misaligned with our other, less dominant selves. Du Bois would later on reformulate this splitting of the selves into the concept of "twoness."

Although the work of William James was highly influential in theorizing the self as a social construct, the most important sociological theorist of the self was George Herbert Mead. For Mead, what characterizes the self is that "it is an object to itself" (1964, p. 200). The self emerges through the process of social interaction as a result of the ability of people to reflect on themselves and their actions by taking the position of other individuals or the community as a whole. In other words, the self develops from internalizing the view that others have of us. This process takes place in two stages: First, children internalize the viewpoints of specific individuals, most likely those of their parents. As they grow up, they learn to take in the views of larger groups, and finally they are able to internalize the views of society in general—which Mead refers to as the "general other."

Mead uses the metaphor of the game to describe this process. We learn to play a game by internalizing its rules. Once we do that, we can fulfill any role in the game because we know what is expected from us. In internalizing the positions of one's community towards different aspects of cooperation and interaction, the self "reflects the unity and structure of the social process as a whole ..." (Mead 1964, p. 208). According to Mead, only when a person "takes the attitudes of the organized social group to which he belongs ... does he develop a complete self" (1964, p. 219). 
Mead emphasizes the mind's ability to symbolize - to attach shared meanings to signs beyond their specific situation. It is this ability to symbolize that characterizes human communication and that allows individuals to understand the viewpoints and take the positions of their community. The capacity to communicate through symbolization is also what allows for the constant expansion of society, and for universal recognition. Communication allows individuals to recognize and come to understand new people that they come in contact with, and in this way, it allows them to expand the boundaries of society. Communication and recognition are also the basis for democracy, as those elements allow people to acknowledge the rights of others in society.

Mead also argues that lack of recognition can hamper the development of the self, stating that if a person is denied recognition, "if others could not take his attitude in some sense, he could not have appreciation in emotional terms, he could not be the very self he is trying to be" $(1964$, p. 278$)$. This, he asserts, is particularly the case in caste societies, where the lack of common attitudes "cut down the possibility of the full development of the self" (Mead 1964, p. 272). In discussing caste society, Mead makes brief references to India and the European middle ages, yet he does not think of the effects of the American construction of race on the self. Mead and Du Bois had parallel careers. Both were students of William James at Harvard and both studied in Germany during the 1890s. Yet, they theorized the process of self-formation in very different ways.

A third important classical theorist of the self was Charles Horton Cooley. Although Cooley does not figure as centrally within the sociological canon as Mead, his work is significant for our argument because he intuits the effects of lack of recognition on racialized subjects. Cooley (1956) coined the concept of the "looking glass self." He argued that individuals learn who they are by viewing themselves through the imagined eyes of others. It is only through communication and recognition that people can afford to imagine how they are seen by others. As did James, Cooley (1956) emphasized that recognition is a human need. He argued that people need "fellowship and that appreciation by others which gives his self social corroboration and support" (Cooley 1956, p. 261). Yet, he was aware that not everyone received social recognition. Reflecting on race (and being an immigrant) he asserts:

The immigrant has for the most part been treated purely as a source of labor, with little or no regard to the fact that he is a human being, with a self like the rest of us. ... The negro question includes a similar situation. There is no understanding it without realizing the kind of self-feeling a race must have who, in a land where men are supposed to be equal find themselves marked with indelible inferiority (Cooley 1956, p. 262).

Cooley intuits the effect of lack of recognition on the self-formation of racialized groups, but he does not develop this point.

Perhaps it was Alfred Schutz (1967) who came closest to addressing the effects of lack of communication and interaction in the construction of intersubjectivity. In his phenomenological description of the social world, Schutz distinguishes between consociates - those whom we share a common social space and with whom we interactand contemporaries - those who live in our times but we do not encounter in everyday life. As we distance ourselves from our everyday experiences the world becomes more opaque. We get to know our consociates and test our ideas about them through interaction. But we can only know our contemporaries using the ideal types that emerge in our everyday life. Our contemporaries are opaque to us in the same way that those who live behind the veil are invisible to Whites who can only think of them within 
the rubric of their existing ideas. But Schutz's analysis of the social world does not address the power relations and exclusionary dynamics involved in racialization. Our contemporaries are potential consociates; what separates us from them is distance. The world behind the veil, though, is not the distant world of contemporaries. It is an adjacent world that Whites do not see. As Anne Rawls argues: "While Black and White appear to occupy the same world geographically, they rarely occupy the same interactional space" (2000, p. 244).

The classical theorists of the self were aware of the negative effects of lack of recognition. None of them, however, devoted much attention to consider the millions of Americans who, at the time of their writing, lived in this very condition. Du Bois's work fills this unresolved gap in the theorizing of the self. The theory of Double Consciousness brings to the fore what the other classical theorists of the self could not see: the presence of the veil (an intangible boundary that affects the perceptions of and relations between racializing and racialized subjects). Instead of a mere endnote, the question of lack of recognition for the racialized subject is central to Du Bois's work.

Du Bois's theorizing emerges from his own encounter with racialization. In Dusk, he states that "had it not been for the race problem early thrust upon me and enveloping me, I should have probably been an unquestioning worshiper at the shrine of the social order and economic development into which I was born" (Du Bois 1940, p. 27). The concrete and everyday experiences of racialization led Du Bois down the path of critical race theory.

Du Bois introduces the theory of Double Consciuosness in the first essay in Souls, entitled "Of Our Spiritual Strivings." There he describes the phenomenological experience of racialization for the Black American:

[A] sort of seventh son, born with a veil, and gifted with second-sight in this American world-a world which yields him no true self-consciousness, but only lets him see himself through the revelation of the other world. It is a peculiar sensation, this double-consciousness, this sense of always looking at one's self through the eyes of others, of measuring one's soul by the tape of a world that looks on in amused contempt and pity. One ever feels his two-ness - an American, a Negro; two souls, two thoughts, two unreconciled strivings; two warring ideals in one dark body (Du Bois 1903, p. 2).

In this short but significant paragraph Du Bois poses three elements to the theory of Double Consciousness: the veil, twoness, and second sight.

The first element is the veil that separates the races-in other words, the color line. This is a constitutive structural element of racialized modernity and it also structures the way in which subjects situated in different sides of the veil see and experience their social world. For the racializing subject, the racialized subject is invisible. Therefore, the racializing subject cannot take the position of the racialized (Rawls 2000). Whites project their own constructions of Blacks onto the veil, and in this way the veil works as a one-way mirror: those on the dominating side of the veil see their projections of the racialized reflected on it. On the other hand, the projections of Whites onto the veil become realities that Black subjects have to process in their self-formation.

The internal processing of the external gaze gives rise to the second element of Du Bois's theory: the sense of twoness. Twoness means that within the process of selfformation the racialized takes the position of two different worlds-the Black world, which they intersubjectively construct behind the veil, and the White world, which dehumanizes them through lack of recognition. The third element of the theory of Double Consciousness is second sight. In a world where the racialized can "only see 
himself through the revelation of the other world," this "gift" forces the Black subject on the one hand to contend with their constant dehumanization, but, on the other hand, allows him or her to glance into the White world, creating the possibility of neutralizing the mirroring effects of the veil (Sawyer forthcoming).

Critics of the theory of Double Consciousness assert that it just expressed common ideas about twoness and alienation present in Du Bois's time. Furthermore, they argue that the theory was just articulated by Du Bois in "Of Our Spiritual Strivings" in Souls and never taken up again (Dennis 2006a, 2006b; Reed 1997).

It is true that the idea of twoness was indeed present in the thinking of Du Bois's contemporaries, but Du Bois gave it a different and particular meaning. It is also true that Du Bois only laid out the conceptual framework for the theory of Double Consciousness in "Of Our Spiritual Strivings." Yet, those concepts sketched in Souls informed his vast analysis of the lived experiences of Blacks and Whites and his analysis of racialized modernity.

Du Bois developed the theory in the context of the life of Blacks in the South at the turn of the twentieth century. The language that he used is that of Blacks and Whites, which was the racial context of the time. However, along his life Du Bois realized that racialization was a global phenomenon. As he asserts in Dusk, when he was young he thought that racialization was a particular characteristic of the United States, but later on realized that this was a global system and "that the majority of mankind has struggled through this inner spiritual slavery ..." (Du Bois 1940, p. 137). For this reason, in this paper, we write interchangeably about Black and White subjects and racialized and racializing subjects.

\section{THE PHENOMENOLOGY OF RACIALIZED SUBJECTIVITY}

In this section of the article we look closely at how Du Bois deploys the theory of Double Consciousness in Souls and Dusk. Souls is a text that sociologists, with few exceptions, do not embrace (Wortham 2011). Charles Lemert (1994), however, argues that it should be considered a canonical text in the discipline. For him, the fact that the discipline does not acknowledge Souls is an example of the invisibility of the work that hails from behind the veil. Part of the essays in Souls-such as "Of the Black Belt" or "Of the Search of the Golden Fleece"-are descriptions of the social and economic structure of the South and the place and predicament of African Americans within it. Sociologists should have no problem recognizing these as examples of community studies. Other essays—such as "Of The Meaning of Progress," "Of The Coming of John," and "Of the Faith of Our Fathers"-are analyses of the lived experience and the racialized subjectivity of Blacks in the South. The latter are the essays that concern us in this paper. These essays have an empirical base and some elements of ethnographic description. The empirical material was Du Bois's observations during the time he spent among those communities while studying at Fisk or teaching at Atlanta University. But the key point of those works is Du Bois's analysis of the lifeworld of African Americans in the South, specifically the phenomenological description of how the world behind the veil is experienced and the different ways in which Blacks respond to the presence of the veil. Du Bois not only illuminates the phenomenological structures of experience of African Americans - the veil, twoness, and second sight-he also goes on to describe the particular racialized subjectivity, the "ensemble of modes of perception, affect, thought desire and fear that animate acting subjects," that emerges out of these experiences (Ortner 2006, p. 107). 
Whereas at least a few sociologists embrace Souls, Dusk is altogether ignored by the discipline. Yet, in Dusk, through a reflection on his own life, Du Bois develops a powerful analysis of how the concept of race was understood and operated during his lifetime, both in America and around the world. Dusk presents a critical analysis of the concept of race through an examination of Du Bois's own second sight and practices and the second sight and practices of those around him. Du Bois points out that although the book is organized as an autobiography, his life "is a dissgressive illustration and exemplification of what race has meant in the world in the nineteenth and twentieth centuries," adding that the "peculiar racial situations and problems could best be explained in the life and history of one who has lived them. My living gains its importance from the problems and not the problems from me" (Du Bois 1940, p. 221). Here, introspection serves on the one hand to develop a phenomenological analysis of racialization-including an insightful study of the lifeworld of White Americans-but also to link lived experiences to a broader analysis of the intersections of class, race, and colonialism. The link between the analysis of self-formation and the racialized structure of the world is one of the key elements of Du Bois's theorizing.

In his reflections upon the fiftieth anniversary of Souls, Du Bois stated that he thought about updating the book but decided to leave it as first printed because it reflected what he thought in 1903 and he hoped that other works would reflect his evolving thought. This is indeed what Dusk does. Dusk is the realization of the research program that started with Souls. Neither Souls nor Dusk were written as scholarly texts. Yet, their analysis of racialization and self-formation - that we present below-makes these two books key texts for sociological theory.

\section{OF THE VEIL}

The main point of the theory of Double Consciousness is that the presence of the veilthe central structural element of racialized modernity - prevents the full recognition of the humanity of racialized groups. The veil structures the lived experience, selfformation, and perception of the world for both racialized and racializing subjects. The invisibility of those who live behind the veil means that there is no process of mutual recognition or true communication between racializing and racialized subjects (Lemert 1994).

In Dusk, Du Bois shows that no matter how clearly, articulately, or sincerely the people within the veil present themselves, the White world either does not hear, or completely misrecognizes what the people within the veil try to convey. Invoking Plato's Allegory of the Cave, Du Bois describes life behind the veil as being imprisoned in and cut off from the dominant world of Whites:

It is as though one, looking out from a dark cave in a side of an impending mountain, sees the world passing and speaks to it; speaks courteously and persuasively, showing them how these entombed souls are hindered in their natural movement, expression, and development; and how their loosening from prison would be a matter not simply of courtesy, sympathy, and help to them, but aid to all the world. One talks on evenly and logically in this way, but notices that the passing throng does not even turn its head, or if it does, glances curiously and walks on. It gradually penetrates the minds of the prisoners that the people passing by do not hear; that some thick sheet of invisible but horribly tangible plate glass is between them and the world (Du Bois 1940, pp. 130-131). 
At the heart of the matter, Du Bois is preoccupied with how the veil distorts the Black subject to the extent that their humanity becomes unrecognizable to others. Confronted with the systematic ignorance on the part of the world outside the cave:

[T] he people within may become hysterical. They scream and hurl themselves against the barriers, hardly realizing in their bewilderment that they are screaming in a vacuum and unheard and that their antics may actually seem funny to those outside looking in (Du Bois 1940, p. 131).

Here in this paragraph we see the effects of lack of recognition-as postulated by James and Cooley-on the lives of African Americans. This state of despair, however, is a symptom of being a racialized subject in American society, not an ontological state of being. As Shawn Smith compellingly argues, Du Bois "describes the struggle of a healthy mind forced to confront and inhabit a perverse world; pathology finally resides not in an African American brain but in the American social body" (2000, p. 29).

The analysis of Double Consciousness in both Souls and Dusk emphasizes the oppressive character of the racialized world and its consequences for the racialized subjects. Yet, there is a constant tension running through Du Bois's work between the description of the oppressiveness of the racialized world and the constant striving of racialized subjects to shape their world. Du Bois's portrayal of the racialized world is not merely one of oppression and suffering but also one of dignity, self-assertion, and creativity. The veil creates a lifeworld distorted by a series of dualities: a duality of agency within an oppressive system, a duality in the formation of the self, and a duality in the understanding of the word. This duality runs through his analysis of twoness and second sight.

\section{OF TWONESS}

Du Bois introduces the concept of twoness as the feeling of being both an American and a Negro. He describes this as having "two souls, two thoughts, two unreconciled strivings; two warring ideals in one dark body" (Du Bois 1903, p. 2). The racialized do not have the option, as Mead would have it, to take the position of the whole community (Rawls 2000); instead, their self-formation is affected by taking the position of the two communities to which they belong - the dominant community that denies their humanity and their own community which is a source of support and an arena of agency. Between these two worlds there is a constant tension among the oppressiveness of the veil, on the one hand, and the agency and creative practices of the racialized population, on the other. Speaking of his own personal interaction with the dominant world, Du Bois reflects:

I lived in an environment which I came to call the White world. I was not an American; I was not a man; I was by long education and continual compulsion and daily reminder, a colored man to a White world; and that White world often existed primarily, so far as I was concerned, to see with sleepless vigilance that I was kept within bounds. All this made me limited in physical movement and provincial in thought and dream. I could not stir, I could not act, I could not live, without taking into careful account the reaction of my White environing world (1940, pp. 135-136).

Although seemingly all-consuming, the White world does not fully determine the selfformation of the racialized subject. Du Bois reminds us that that the "Negro American 
has for his environment not only the white surrounding world, but also, and touching him usually more nearly and compellingly, is the environment furnished by his own colored group" (1940, p. 173). In Souls, Du Bois takes up religion and the church as the primary sites of such world-building (Wortham 2011). In the essay "Of the Faith of the Fathers," he asserts that the Black church is "the social center of Negro life in the United States, and the most characteristic expression of African character" (Du Bois 1903, p. 123). He describes the church as being the hub of the activities of Black communities:

Various organizations meet here-the church proper, the Sunday-school, two or three insurance societies, women's societies, secret societies, and mass meetings of various kinds. Entertainments, suppers, and lectures are held beside the five or six regular weekly religious services (Du Bois 1903, p. 123).

Du Bois also emphasizes the centrality of music in the everyday experience of Blacks. He writes:

The Music of Negro religion is that plaintive rhythmic melody, with its touching minor cadences, which, despite caricature and defilement, still remains the most original and beautiful expression of human life and longing yet born on American soil. Sprung from the African forests, where its counterpart can still be heard, it was adapted, changed, and intensified by the tragic soul-life of the slave, until, under the stress of law and whip, it became the one true expression of a people's sorrow, despair, and hope (Du Bois 1903, p. 122).

What Du Bois is describing here is a rich cultural and social world behind the veil, a world invisible to the dominant world.

Du Bois poses twoness as the phenomenological description of the condition of self-formation behind the veil. But he recognizes that twoness can lead to different responses to the veil. This is clearly articulated in his essay on Booker T. Washington in Souls. In a short paragraph in that essay, Du Bois proposes a typology of three modes in which racialized groups deal with the veil. He states:

But when to earth and brute is added an environment of men and ideas, then the attitude of the imprisoned group may take three main forms, - - feeling of revolt and revenge, and attempt to adjust all through and action to the will of the greater groups; or finally, a determined effort at self realization and self-development despite environing opinion (Du Bois 1903, p. 30).

One response to the veil is self-assertion in spite of the oppressive context, and Du Bois gives the example of the establishment of the Black Episcopal church in Philadelphia and New York as instances of self-development. This was Du Bois's choice, and he advocated various tactics during his life to go along this path: from his early belief in science and the talented tenth during his Atlanta years, through his activism for civil rights during his time with the National Association for the Advancement of Colored People (NAACP), to his advocacy of group self-organization at the end of his life. But he realized that his own response to the veil was not the only possible one. A second response is rebellion, and Du Bois cites Gabrielle's rebellion and the Haitian revolution as examples of this. A third response is assimilation, and it is clear in his scathing critique that for Du Bois, Washington had unabashedly adopted this path. For Du Bois, adopting a project of assimilation without recognition was a losing proposition 
for Blacks as it denied them the possibility of full acceptance and self-consciousness from the start.

Du Bois returns to this analysis of the different forms of responding to the veil in Dusk. There, he analyzed the ways in which educated young Blacks deal with twoness. He argues that the responses range between two poles. On the one hand are those that "avoid every appearance of segregation" (Du Bois 1940, p. 186). This group avoids contact with Black organizations and attempts to join the world of Whites-an attempt at assimilation. At the other end there is a group that "prides himself on living with 'his people"” (Du Bois 1940, p. 187) and attempts to distance themselves from Whites whenever possible. For Du Bois, each of these responses has a cost. The first group has to deal with rejection from the White world, as the "thick plate glass" (Du Bois 1940 , p. 131) of the veil keeps them from truly assimilating into mainstream society. The second group lives in an isolated cultural world. Du Bois argues that neither of these groups obtains recognition or can participate in the communication process to define their reality and build their world. In between these two groups are "all sorts of interacial patterns, and all of them theoretically follow the idea that Negroes must only submit to segregation "when forced" (Du Bois 1940, p. 187). The practical result is a "crystallization of the culture elements among colored people into their own groups for social and cultural contact" (Du Bois 1940, p. 187).

In Dusk, Du Bois also returns to the topic of Black agency and the vitality of the world behind the veil. There he discusses different cultural, social and political initiatives - in addition to the church - that take place beyond the veil. He points to movements to advance literature and art; he describes the organization of demands for Black health; and he proposes the launch of consumer cooperatives to put the purchasing power of the Black population at the service of community economic development. These initiatives embody the constant striving of African Americans for recognition, for the ability to shape their selves and their world-in other words, for full emancipation and equality.

\section{OF SECOND SIGHT}

Second sight then is the potential ability of the racialized to see the world behind the veil. In Souls, Du Bois describes the experience of living behind the veil as living in "a world which yields him no true self-consciousness, but only lets him see himself through the revelation of the other" (Du Bois 1903, p. 2). Second sight creeps in as the awareness of their invisibility and of the world beyond the veil gradually becomes apparent to Black subjects. What is important is not only the abject condition of invisibility but the "gift" of awareness that is granted through this second sight (Sawyer forthcoming). The veil, thus, has a doubling effect: It creates a barrier of recognition between the Black and White worlds, and it leads the Black person to misrecognize his or her own self. Yet, turning the screw on Plato's allegory, while the prisoners in the cave have a distorted view of themselves, they also have the possibility of glimpsing at the world beyond the veil.

The racialized have no choice but to see themselves through the eyes of the racializing as reflected on the veil. This situation allows them to, at least partially, suspend the optics of the veil and see other possibilities for organizing the world (Blau and Brown, 2001; Smith 2004). In his analysis of the lived experience of African Americans, Du Bois points to different ways in which this ability may emerge and develop. We can see this process in the essay "Of the Meaning of Progress." In this essay, Du Bois narrates his experience teaching in a poor, rural Black community in Tennessee during one of 
the summers during his Fisk years. He describes the community in which he taught as having a "half awakened common consciousness" that he describes in the following paragraph:

[T]here was among us but a half-awakened common consciousness, sprung from common joy and grief, at burial, birth, or wedding; from a common hardship in poverty, poor land, and low wages; and, above all, from the sight of the Veil that hung between us and Opportunity. All this caused us to think some thoughts together; but these, when ripe for speech, were spoken in various languages. Those whose eyes twenty-five and more years before had seen "the glory of the coming of the Lord," saw in every present hindrance or help a dark fatalism bound to bring all things right in His own good time. The mass of those to whom slavery was a dim recollection of childhood found the world a puzzling thing: it asked little of them, and they answered with little, and yet it ridiculed their offering. Such a paradox they could not understand, and therefore sank into listless indifference, or shiftlessness, or reckless bravado. There were, however, some-such as Josie, Jim, and Ben-to whom War, Hell, and Slavery were but childhood tales, whose young appetites had been whetted to an edge by school and story and halfawakened thought. Ill could they be content, born without and beyond the World. And their weak wings beat against their barriers-barriers of caste, of youth, of life; at last, in dangerous moments, against everything that opposed even a whim (Du Bois 1903, p. 43).

Here, the distortions of the veil lead to different forms of subjectivity and to different degrees of awakening of second sight. The veil distorts everybody's view of the world and the self, but it does it in different ways- "as spoken in various languages," in Du Bois's compelling description. But in all cases, the veil stands between racialized people and the world of opportunity that they are able to glimpse.

The process of emergence of the second sight is most developed in "Of the Coming of John." Told from the perspective of a faculty member at a fictional College, Du Bois poetically depicts the changes in John's second sight through the use of narrative fiction. Growing up as a young man in the Jim Crow South, Black John is completely uncritical of his condition and unaware of his place in the world. In this state, the Whites in his town viewed him as "good natured." Yet, much to their dismay, his mother decided to send young Black John away to college. White John was off to Princeton at the same time. Although Black John and White John grew up together, and were even playmates, they were seldom thought of in the same mind. Du Bois writes, "And yet it was singular that few thought of two Johns- for the black folk thought of one John, and he was black; and the white folk thought of another John, and he was white. And neither world thought on the other world's thought save with a vague unrest" (Du Bois 1903, p. 148).

Black John goes to college, but at the beginning he is not into studying. As a result of John's lackadaisical attitude and wanting performance, the faculty decided to suspend him for a term. This woke him up and stirred a grave seriousness in John; a seriousness never left his face again, and John returned to college with a new vision of the "world," Black and White. It was at his return to college that the "gift" of secondsight came upon him:

He had left his queer thought-world and come back to a world of motion and men. He looked now for the first time sharply about him, and wondered how he had seen so little before. He grew slowly to feel almost for the first time the Veil 
that lay between him and the white world; he first noticed now the oppression that had not seemed oppression before .... (Du Bois 1903, p. 149).

Black John's access to education and encounter with the White world prompts the emergence of second-sight - a startling, yet gradual revelation that allows him to see the structures of his racialized environment and the ways in which he is situated and constrained in and around the veil.

Later in the essay, Black and White John encounter each other at an opera house in NYC during which Black John is made to give up his seat at the behest of White John. This enrages Black John and makes him attend to his "destiny" to go back and uplift the Negro back in his hometown of Altamaha, GA, after seven long years of being away. The ride home was unpleasant because he was made to sit in the Jim Crow car, as always, but this time his second-sight lead him to be acutely aware of it. The return home portrays the transformation of John's understanding of the world. What is interesting here is that with this new sight, Black John finds himself disjointed and finds it difficult to navigate comfortably within the White and Black lifeworlds. Upon his return, the Blacks felt that he was aloof and the Whites (not much differently) felt that he was uppity. The mayor warned John about infecting his Black pupils with his notions of equality and making them discontent and unhappy.

Both essays end in tragedy, and they show the unique dilemma of racialized subjectivity. Laden in them is the dimness of possibility for something different, and at the same time the overbearing presence of the veil. As with twoness, Du Bois's work on second sight points to dualities in the lived experience of racialized people. Although second sight grants the Black subject the tools to understand the world constructed around the veil, it does not avail the subject from his or her subordinate positionality.

In Souls, the emergence of second sight was only for those who possessed an internal desire to learn - in going away to college for Black John and through learning in a small classroom for select students in "Of The Meaning of Progress." While Du Bois always held higher education — and the role of people with higher education-in high esteem, over time he developed a more nuanced understanding of the role of knowledge. Initially, he thought that addressing the veil was a matter of scientific inquiry:

The Negro problem was in my mind a matter of systematic investigation and intelligent understanding. The world was thinking wrong about race, because it did not know (Du Bois 1940, p. 58).

This belief led Du Bois to undertake the systematic study of Black communities and to produce a number of impressive sociological works-from The Philadelphia Negro to the Atlanta studies-whose qualities have stood the passage of time. But the practice of positivist science led Du Bois to understand that this was not the answer to the problem of lack of recognition. He articulates this in powerful language:

Two considerations thereafter broke in upon my work and eventually disrupted it: first, one could not be a calm, cool, and detached scientist while Negroes were lynched, murdered and starved; and secondly, there was no such definite demand for a scientific work of the sort that I was doing . . . (Du Bois 1940, p. 67).

Du Bois concluded that scientific research was not the answer to the veil. His words were not heard, even though they were conveyed in a language that enjoyed a great 
deal of legitimacy. The power of the veil to hide and distort was stronger than the clearest voices coming from within the cave. This led Du Bois down the path of political activism, first at the NAACP and the directorship of The Crisis, and then through tireless advocacy of group organization for self-development, self-preservation, and a protracted struggle for equality. Whereas in Souls the second sight emerges as a result of access to education, in Dusk Du Bois describes how his encounters with the daily practices of racialization made him question the world around him and how the practice of resisting the veil expanded his second sight.

\section{OF WHITENESS}

Second sight provides a sober look at the racialized world and, by extension, at the world of Whites. Whereas the racialized is invisible for the racializing, the former can develop an understanding of the latter, one that is less encumbered than the one that the racializing subject has of himself (Blau and Brown, 2001). In Dusk, Du Bois dedicates a full chapter to the study of the natural attitude of Whites. He conducts this analysis through conversations with two imaginary White friends.

Du Bois makes two points in these imagined conversations. The first point concerns the relationship of Whites to Blacks. Here, Du Bois points to the duality between the power to define the social world and the inability to see the social world fully. In his first imaginary dialogue, Du Bois emphasizes the blindness of the White position and the inability of Whites to fully recognize the humanity of other people. In explaining the White's basic understanding of the world, Du Bois states, "His thesis is simple: the world is composed of Race superimposed on Race; classes superimposed on classes ..." (Du Bois 1940, p. 140). The White person presupposes himself as ontologically superior but does not acknowledge himself as an active participant in domination or oppression. This allows him to rationalize the racial order of society, as he sees it, and take pity (or contempt) on Blacks.

Mead points out that in caste systems people cannot develop a full self because the limits to the common attitudes preclude individuals from internalizing the full social process in which they participate. This is the situation that Du Bois describes. The racializing cannot take the position of the whole community because he does not recognize an important part of the community in which he lives (Rawls 2000). As a result, the racializing subject does not see his own position as oppressor within the system of racialization. If the Black subject suffers misrecognition because their humanity is denied, the White subjects misrecognize themselves because they are unable to see their role in denying the humanity of the other (Lemert 1994). If the corollary of the veil for the racialized is the devastating anguish of not being recognized, for the racializing it is constant and persistent denial. As Judith Blau and Eric Brown put it, "Blacks bear the burden of Twoness but whites are deluded by how they position themselves in their invented hierarchy" (2001, p. 221).

The second point Du Bois makes concerns the relationship of the White subjects to themselves. Here, Du Bois points to another duality - that between Whites' ideals of justice, on the one hand, and their blindness to their position in relation to the veil (which invalidates those ideals), on the other. For this part of the analysis, Du Bois launches into another dialogue with an imaginary White friend by stating:

He represents the way in which my environing white group distorts and frustrates itself even as it strives toward Justice and all because of me. In other words, because of the Negro problem (1940, p. 153). 
Du Bois argues that the White subject lives in a perpetual contradiction between aspirations for justice and a good society and the need to justify the unjust order of White supremacy. He describes the different cultural codes that inform the world of Whiteness, cultural codes that emphasize contradictory norms. On the one hand, Du Bois points to a Christian cultural code that emphasizes peace, good will, the Golden Rule liberty, and poverty. On the other hand, a White Man cultural code built on war, hate, suspicion, exploitation, and empire. (Du Bois also analyzes a Gentleman code and an American cultural code.) These codes are internally coherent, but they contradict each other. The contradiction is based on the fact of race. The White subject cannot live up to his or her aspirations for justice because of the reality of racial inequality. When this contradiction needs to be resolved, the White subject almost invariably chooses oppression, justifying it as the defense of civilization. In Du Bois's analysis, the racializing subject lives in bad faith (Gordon 2000).

In his analysis of Whiteness, Du Bois presents an elaborated understanding of race as a social construction. He delivered a strong critique of biological understandings of race in his early essay on "The Conservation of Races" (Du Bois 1987). In that essay, he equates race with historical peoplehood but holds to romantic notions of common blood and destiny. In Dusk, he describes race as a "cultural, sometimes an historical fact" (Du Bois 1940, p. 153). He argues that the internal diversity within groups and the mixing of populations renders any scientific definition of race invalid. He is asked by one of his imaginary White friends how he would then know who is Black. His answer is as simple as it is powerful: "I recognize it quite easily and with full legal sanction; the black man is a person who must ride 'Jim Crow' in Georgia" (Du Bois 1940, p. 153). Race is a product of social interaction and institutionalized power. He asserts:

Thus it is easy to see that scientific definition of race is impossible; it is easy to prove that physical characteristics are not so inherited as to make it possible to divide the world into races. ... [A]ll this has nothing to do with the plain fact that throughout the world today organized groups of men by monopoly of economic and physical power, legal enactment and intellectual training are limiting with determination and unflagging zeal the development of other groups (Du Bois 1940, pp. 137-138).

This analysis of race informs Du Bois's explanation of the natural attitude of the racializing. Anticipating Pierre Bourdieu (1990), he explains the blindness and self-justification of Whites in terms of a combination of economic interest and habitus (i.e, "systems of durable, transposable dispositions" that "generate and organize practices and representations" (Bourdieu 1990, p. 53)). Whites have economic interests to defend. Du Bois makes the case that colonialism and the exploitation of racialized people worldwide are central to the construction of the White natural attitude. But this is not all. He adds:

The present attitude and action of the white world is not based solely upon rational, deliberate intent. It is a matter of conditioned reflexes, of long followed habits, customs and folkways, of subconscious trains of reasoning and unconscious nervous reflexes (Du Bois 1940, pp. 171-172).

Subjectivity — which is informed by habitus and irrational thinking — and social structure are tied in Du Bois's theorization. Subjectivity constructs social structure as much as social structure constructs subjectivity. Through his analysis of Whiteness, Du Bois 
builds on the theory of Double Consciousness to develop a constructionist theory of race anchored in a critique of racialized modernity.

\section{CONCLUSION}

Sociology has made important advances in the study of race. Whether we look at the study of racial attitudes (Bobo 2000), ethnographies of different racialized groups (Young 2004), the analysis of color-blind racism and race as a structural system (Bonilla-Silva 2006), or the study of Whiteness (Feagin 2013), race has become a central topic in sociology. This has improved American sociology and brought Du Bois's contributions to light (Morris 2007). In this paper we stated our case for considering Du Bois a sociological theorist. Du Bois was a scholar of race, but he was also a theorist of racialized modernity - an aspect of his work that has not received the attention it deserves.

We showed how the theory of Double Consciousness addressed gaps in the theorizing of of James, Mead, and Cooley with regard to the formation of the self. These theorists did not pay attention to the way in which lack of mutual recognition and communication affects self-formation in a racialized society. Du Bois's theory of Double Consciousness-the phenomenological description of the self-formation of racialized subjects-shows that in a racialized society there is no true communication or recognition between racialized and racializing subjects. The racialized is forced to see him or herself through the eyes of the racializing, a group that does not recognize the racialized's humanity, while the racializing are blind to their own position and participation in the racializing system.

Furthermore, the theory of Double Consciousness is relevant to contemporary debates in social theory. Jürgen Habermas (1989), for example, builds on Mead among others to develop his theory of communicative action. Recognition is central to this theory because without it, it is impossible to reach the consensus based on deliberation and argumentation that is the core of communicative rationality. Yet, the theory of Double Consciousness asserts that as long as there is racialization there cannot be communication on equal terms between racialized and racializing subjects. Therefore any consensus is the product of power relations, not of deliberation. Habermas recognizes the possibility of distorted communication, but he does not link it to race or put racialization at the center of his analysis of the social system. A Du Boisian approach emphasizes that in a racialized society the power dynamics preclude the possibility of everybody participating in the formation of a social consensus on equal terms. The racialized lifeworld is shared under conditions of inequality and oppression that prevent the development of communicative rationality.

Jeffrey Alexander's (2006) analysis of the civil sphere recognizes the possible exclusions inherent in the binary discourses that structure civil society and the role race has played in those exclusions. Furthermore, he states the importance of social movements in challenging those binaries and achieving inclusion. The argumentation that informs communicative action is carried out by social movements making claims for repositioning groups vis-à-vis the binaries of civil society. Alexander shows how the civil rights movement pressed claims of universality and inclusion present in America's civil sphere. Alexander's analysis emphasizes solidarity and universality as inherent possibilities of the civil sphere, but it does not give enough weight to the way the persistent exclusion of race structures civil society and limits the development of solidarity. As Herbert Blumer (1965) presciently saw, the civil rights movement only partially breached the exclusions of the color line. A Du Boisian approach that 
emphasizes the pervasive presence of racialization in the development of the self and in the processes of recognition and communication between people from different ethnoracial groups is a more accurate analysis of the dynamics of the civil sphere than Alexander's.

Howard Winant (2009) proposes an example of such an approach in The World is a Ghetto. Winant builds directly on Du Bois to expand Wallerstein's theory of the world system by putting racialization and the cultural constructions that it informs (in terms of identity, group, and nation formation) as one of the pillars of the modern world system. Winant puts the veil and double consciousness at the center of his analysis of the racialized world system. He acknowledges the changes that took place in the dynamics of racialization as the consequence of what he terms "the break"- the political and social changes brought by the civil rights and anti-colonialist movements of the postWorld War II period-but he relies on the theory of racial formation to account for how the veil and double consciousness operate in the contemporary period structuring institutions and relations between groups.

In this paper we also highlighted the importance of Du Bois's methodological contributions. The key to his theorizing is the phenomenological description of the lived experience in a racialized world. In his analysis, Du Bois employs a range of techniques, including autobiographical reflection, historical analysis, and ethnography, and shows the analytical potential of using biography and experience as building blocks to develop theory. These are methodologies applied in other critiques of racism and colonialism-such as the works of Frantz Fannon (1952) and Albert Memmi (1965)—and taken up later by the different branches of ethnic studies. American sociology in general has stayed away from these methodologies, but in this essay we have shown how they can contribute to the development of sociological theory and analysis. After all, the advantage of sociology, as C. Wright Mills argued, is in connecting the personal experience with the structural and historical contexts in which it develops.

Acknowledging Du Bois's theoretical work is important both in terms of the history of the discipline and in terms of its relevance for the analysis of the contemporary world. The theory of Double Consciousness offers much to sociology in terms of advancing theories of racialized subjectivity and racialized social systems. It provides a robust analytical framework that allows for the multi-level examination of individual-level processes - such as the formation of the self - within the broader contexts of a racialized world, offering the ability to conduct phenomenological analyses of particular groups while accounting for the macro-structural processes that condition them. The theory of Double Consciousness also presents a framework for conducting cultural analyses of the racialized and the racializing without unduly pathologizing individual groups or proposing essentializing cultural explanations for what seem to be deviant behaviors. It is these theoretical and methodological contributions that make Du Bois a foremost sociological theorist, a theorist of racialized modernity.

Corresponding author: Professor José Itzigsohn, Department of Sociology, Maxcy Hall, Brown University, Box 1916, 108 George Street, Providence, RI 02912. E-Mail: Jose_Itzigsohn@ Brown.edu.

\section{REFERENCES}

Alexander, Jeffrey C. (2006). The Civil Sphere. Oxford, UK: Oxford University Press.

Anderson, Elijah (1996). Introduction. In W. E. B. Du Bois, The Philadelphia Negro: a Social Study, pp. ix-xxxvi. Philadelphia, PA: University of Pennsylvania Press.

Anderson, Elijah (Ed.) (2000). The Study of African American Problems: W. E. B. Du Bois's Agenda, Then and Now. Thousand Oaks, CA: Sage Publications. 
Blau, Judith R., and Eric S. Brown (2001). Du Bois and Diasporic Identity: The Veil and the Unveiling Project. Sociological Theory, 19(2): 219-233.

Blumer, Herbert (1965). The Future of the Color Line. In John C. McKinney and Edgar T. Thompson (Eds.), The South in Continuity and Change, pp. 322-336. Durham, NC: Duke University Press.

Bobo, Lawrence D. (2000). Reclaiming a Du Boisian Perspective on Racial Attitudes. The Annals of the American Academy of Political and Social Science, 568: 186-202.

Bonilla-Silva, Eduardo (2006). Racism without Racists. Lanham, MD: Rowman \& Littlefield Publishers.

Bourdieu, Pierre (1990). The Logic of Practice. Stanford, CA: Stanford University Press.

Cooley, Charles Horton ([1922] 1956 ed.). Human Nature and the Social Order (in The Two Major Works of Charles H. Cooley). Glencoe, IL: The Free Press.

Dennis, Rutledge M. (1996a). Continuities and Discontinuities in the Social and Political Thought of W. E. B. Du Bois. Research in Race \& Ethnic Relations, 9: 3-23.

Dennis, Rutledge M. (1996b). Du Bois's Concept of Double Consciousness: Myth and Reality. Research in Race \& Etbnic Relations, 9: 69-90.

Du Bois, W. E. B. (1897). The Conservation of Races. The American Negro Academy Occasional Papers, No. 2. Washington, D.C.: Published by the Academy.

Du Bois, W. E. B. ([1903] 1965 ed.). The Souls of Black Folk. London: Longmans, Green and Co. Ltd.

Du Bois, W. E. B. ([1940] 2012 ed.). Dusk of Dawn. New Brunswick, NJ: Transaction Publishers.

England, Lynn, and W. Keith Warner (2013). W. E. B. Du Bois: Reform, Will, and the Veil. Social Forces, 91(3): 955-973.

Fanon, Frantz ([1952] 2008 ed.). Black Skin, White Masks. New York: Grove Press.

Feagin, Joe (2013). The White Racial Frame. New York: Routledge.

Gilroy, Paul (1993). The black Atlantic. Cambridge, MA: Harvard University Press.

Gooding-Williams, Robert (2010). In the Shadow of Du Bois. Cambridge, MA: Harvard University Press.

Gordon, Lewis R. (2000). Existentia Africana. New York: Routledge.

Green, Dan S., and Edwin D. Driver (Eds.) (1995). W. E. B. Du Bois on Sociology and the Black Community. Chicago, IL: University of Chicago Press.

Habermas, Jürgen (1989). The Theory of Communicative Action. Vol. 2. Boston, MA: Beacon Press.

James, William (1890). The Principles of Psychology. Cambridge, MA: Harvard University Press.

Lemert, Charles (1994). A Classic from the Other Side of the Veil: Du Bois's Souls of Black Folk. The Sociological Quarterly, 35(3): 383-396.

Mead, George H. (1964). On Social Psychology. Chicago, IL: University of Chicago Press.

Memmi, Albert ([1957] 1991 ed.). The Colonizer and the Colonized. Boston, MA: Beacon Press.

Morris, Aldon (2007). Sociology of Race and W. E. B. Du Bois: The Path not Taken. In Craig Calhoun (Ed.), Sociology in America: A History, pp. 503-534. Chicago, IL: The University of Chicago Press.

Morris, Aldon, and Amin Ghaziani (2005). Du Boisian Sociology: A Watershed of Professional and Public Sociology. Souls, 7(3-4): 47-54.

Ortner, Sherry (2006). Anthropology and Social Theory: Culture, Power, and the Acting Subject. Durham, NC: Duke University Press.

Rabaka, Reiland (2010). Against Epistemic Apartheid: W. E. B. Du Bois and the Disciplinary Decadence of Sociology. Lanham, MD: Lexington Books.

Rampersad, Arnold (1976). The Art and Imagination of W. E. B. Du Bois. Cambridge, MA: Harvard University Press.

Rawls, Anne Warfield (2000). "Race" as an Interaction Order Phenomenon: W. E. B. Du Bois's "Double Consciousness" Thesis Revisited. Sociological Theory, 18(2): 241-274.

Reed, Adolph L., Jr. (1997). W. E. B. Du Bois and American Political Thought: Fabianism and the Color Line. Oxford, UK: Oxford University Press.

Sawyer, Michael (forthcoming). The Du Boisian V[v]eil[s] Reexamined, Callaloo.

Schutz, Alfred (1967). The Phenomenology of the Social World. Evanston, IL: Northwestern University Press.

Smith, Shawn Michelle (2004). Photography of the Color Line. Durham, NC: Duke University Press.

Winant, Howard (2009). The World is a Ghetto. New York: Basic Books.

Wortham, Robert (Ed.) (2011). The Sociological Souls of Black Folk: Essays by W. E. B. Du Bois. Lanham, MD: Lexington Books. 


\section{Itzigsohn and Brown}

Wortham, Robert A. (2009). W. E. B. Du Bois, the Black Church, and the Sociological Study of Religion. Sociological Spectrum, 29(2): 144-172.

Young, Alford A. (2004). The Minds of Marginalized Black Men: Making Sense of Mobility, Opportunity, and Future Life Chances. Princeton, NJ: Princeton University Press.

Zamir, Shamoon (Ed.) (2008). The Cambridge Companion to W. E. B. Du Bois. Cambridge, MA: Cambridge University Press.

Zuberi, Tukufu (2004). W. E. B. Du Bois's Sociology: The Philadelphia Negro and Social Science. The Annals of the American Academy of Political and Social Science, 595: 146-156.

Zuckerman, Phil (Ed.) (2004). The Social Theory of W. E. B. Du Bois. Thousand Oaks, CA: Sage Publications. 